\title{
Children's Rights in Greek Education (1830s-1920s): Gender, Educational Experiences, School Life
}

\author{
Vassilis A. Foukas \\ Department of Education, School of Philosophy \& Education, Faculty of Philosophy, Aristotle University of Thessaloniki, Greece
}

How to cite this paper: Foukas, V. A. (2018). Children's Rights in Greek Education (1830s-1920s): Gender, Educational Experiences, School Life. The Educational Review, USA, 2(6), 352-359. http://dx.doi.org/10.26855/er.2018.06.004

Corresponding author: Vassilis A. Foukas, Assistant Professor in "History of Education", Department of Education, School of Philosophy \& Education, Faculty of Philosophy, Aristotle University of Thessaloniki, Greece.

\begin{abstract}
The aim of this paper, in brief, is to present the development of children's rights in Greek education since the Greek State's establishment (the 1830s) until the first decades of the 20th century (until the 1920s). The emphasis firstly given on children's rights' to education, on the social origin of pupils -both boys and girls- on the recognition of the universal right in education and on universal schooling for both boys and girls and on the exclusionary experiences of girls from the education in the aforementioned period. In the second part, the emphasis given on children's rights in education that arise by the way in which children participate in the daily school life, namely, on the child as a passive receiver in the 19th-century educational process and in the child-centered approach according to the introduction and diffusion of Progressive Education ideas, and the development of paediatrics and specialist children's clinics.
\end{abstract}

\section{Keywords}

Childhood, Children Rights, School Experience, School Life, Gender, Greece

\section{Introduction}

Childhood as a social and cultural category defined differently in the social space and time, occupied a different position and performed different roles, depending on the age, society, social class, gender, race, ethnicity or religious group (Jenks, 2005; James \& James, 2008). In this context, the history of childhood and children's rights in education are the subject of particular study during the last decades of the 20th century in many countries of Europe and also in Greece. The first attempt for the recognition of the children's rights was made in 1924 by the Geneva Declaration, which adopted in 1959. The adoption of the United Nations Convention on the Rights of the Child becomes in 1989. In 1992 the Convention was ratified by the Greek government. In Greece, the relevant interest was developed, strengthened and furthered by the Institution of Research for the child and the Historical Archive of Greek Youth. The aim of this paper is to present the evolution of children's rights to Greek education since Greek State's establishment (the 1830s) until the first decades of the 20th century (the 1920s). Especially, the emphasis is firstly given on children's rights access to education, e.g. on the social origin of pupils, on the recognition of the universality of the right to children's education and on the compulsory schooling for both boys and girls and consequently the social definition of childhood and the exclusionary experiences from the education of girls during the aforementioned period. Secondly, the emphasis is given on the rights that arise by the way in which the child is participated in the everyday school life, namely from the child's approach to the educational process. This paper follows the historical-interpretive approach. 


\section{Children's Rights to Education}

\subsection{The Right of Access to the Educational Procedure}

At the end of the 18th century, according to the scholars of the era, "koina" (= "common") schools operate throughout the Greek-speaking area for a longer or shorter period of time (Ziogou, 1986). Gradually this situation is changing. There are a lot of "common" schools, but also "kyklopaedias" schools (= secondary education) and higher schools, focusing mainly on areas with developed commercial activity. However, the conditions do not allow us to refer to generalized and systematically organized education since it is characterized by multiplicity in name, in the organization, in teaching, and in the place (Kyprianos, 2004). At the same time, the form of "homeschooling" (= "oikodidaskalia") is particularly developed, a possibility which has only wealthy families (Terzis, 2004). The number of students is gradually widening, and from the early 17th century the first educated women-daughters of prominent Phanariotes appear (Ziogou, 1986).

With the establishment of the modern Greek State the right to education theoretically widened by recognizing the universality of the right to education of children and the universal schooling of boys and girls in primary school, even though the 1834 law defines separate schools for girls wherever this is possible (Dimaras, 1999). Despite the compulsory schooling, however, and the high financial sanctions in cases of non-attendance during the 19th century, the Greek primary education was undereducation, as it is shown in Table 1, which follows.

Table 1. Primary schools and number of students.

\begin{tabular}{|c|c|c|c|c|}
\hline \multirow[b]{2}{*}{ Year } & \multicolumn{3}{|c|}{ Primary schools and number of students } & \multirow[b]{2}{*}{$\begin{array}{c}\% \text { of pupils on the } \\
\text { population }\end{array}$} \\
\hline & Population & $\begin{array}{c}\text { Elementary } \\
\text { Schools }\end{array}$ & Students & \\
\hline 1837 & 680,381 & 151 & 14,996 & 2.20 \\
\hline 1844 & 930,295 & 281 & 26,160 & 2.80 \\
\hline 1853 & $1,042,527$ & 390 & 40,430 & 3.86 \\
\hline 1867 & $1,348,522$ & 1,096 & 57,839 & 4.30 \\
\hline 1874 & $1,437,026$ & 1,197 & 79,454 & 5.52 \\
\hline
\end{tabular}

Source: Tzikas, 2008, p. 4

Inequality in compulsory education certainly has social characteristics. The less educated areas are the poorest, remote geographical areas with the lowest economic growth (Tzikas, 2008). The above inequality takes dramatic dimensions if we concentrate on gender.

Table 2. The gender dimension in primary education.

\begin{tabular}{|c|c|c|c|c|}
\hline \multirow[b]{2}{*}{ Year } & \multicolumn{3}{|c|}{ The gender dimension in primary education } & \multirow[b]{2}{*}{ Number of schoolgirls } \\
\hline & Primary schools male & $\begin{array}{c}\text { Number of } \\
\text { students }\end{array}$ & Girls' primary schools & \\
\hline 1836 & 103 & & 10 & \\
\hline 1848 & 292 & 25,752 & 35 & 3,458 \\
\hline 1867 & 907 & 46,773 & 193 & 11,066 \\
\hline
\end{tabular}

Source: Tzikas, 2008, p. 8

As regards the educational right of girls, the prohibition of coeducation -a characteristic of the social construction of childhood- from 1852 and the separation of the Primary Schools in males and females (= Parthenagogeia), combined with the poor economics of the Municipalities, the stereotypes of Modern Greek society and the operation of many private schools for 
girls (= Parthenagogeia), give other content to the right of access to the girls' education (Ziogou, 2006).

\subsection{Living Exclusion from Education}

Elizabeth Moutzan-Martinegou's (1801-1832) autobiography from island Zakynthos clearly shows how she grew up and how a girl lived in her childhood in the early 19th century. Restricting her at home and her father's intransigence not to allow her further education are characteristic traits that lead the girls of the time to experience exclusion from the "human society", proclaiming social injustice: "I was always closed into a house... I was looking at the walls of the house that kept me locked ... because my father had that old barbaric opinion, which wants women not to learn many letters..." (Martinegou, 1956, pp. 12-13, 26, 56).

At the same time, the example of Evanthia Kairis (1799-1866) from island Andros, who is taught by her brother Theophilos Kairis (1784-1853), Greek, foreign languages and mathematics, knowledge which she, then, transfers to other girls in Kydonies and in Ermoupolis (Ziogou, 1986; Ziogou, 2006) makes it clear that the education of girls in Greece is still vague and non-systematic. Directly to the above is the Greek state's insistence on the prohibition of mixed education and, in fact, the exclusion of girls from secondary education. The example of Marigo Komninou from island Skyros is typical. The Ministry of Education responds to the director of Skyros High School that is with great surprise that he has allowed to examinate two girls, Marigo Komninou and Kali Skouloudaki with the boys. The examination according to the ministry is illegal, since girls are not allowed to attend secondary schools' lessons (Document of the Minister of Education to the director of the Hellenic School of Skyros to Dimaras, 1999, p. 208). While we should particularly emphasize the Ministry's "regulatory speech": "You can not have girls as students".

At the beginning of the 20th century, another girl, Angeliki Panayiotatou (1878-1954) from island Kephalonia underlined her desperate struggle for higher education: “...the environment not only did not help me to continue my work but also I was tired. But I struggled desperately and I won..." (Panayiotatou, 1951, p. 4).

The big problem, therefore, in Greece is the attendance of girls. Although the blade closes with time, even in 1910, girls account for only 30 per cent of the student population (Kyprianos, 2004). Until 1910, there is a perception that each of the three social classes has different educational needs. In this light, the generalization of Primary School, the shift to technical education and the reduction of the number of students in Gymnasium and students (Kyprianos, 2004) are called for. In the Ioannis Tsirimokos' Education Bills, in 1913, whose editor is the philosopher Dimitris Glinos, there is no indication of the different needs of the social classes. On the contrary, education is presented as a common good. The new enlightening concept is summed up in the educational text of the Educational Group in the autumn of 1926 entitled Democracy and Education. Our education program, which states the following: "...All children, boys and girls must be educated at least 18 years of their life in the elementary school and the subsequent general or special vocational or supplementary schools... The organization of schools should be based on children's mental development, their different psycho-consciousnesses and interests, and the needs of the professions. The choice of qualified and special gifted children should be the only criterion for their classification in different types of schools..." (Anagennisis, 1926, pp. 183-184).

\section{Children's Rights in Education}

\subsection{Children and School Life}

The childhood approach in the 19th century based on the theory of the "little adult", and the critical approach to the innovative views of Jean-Jacques Rousseau and Johann Bernhard Basedow (Kitromilidis, 20045) are certainly reflected in the wider school and social life with the absence or individual measures for the protection of the child, the well-being of childhood and the lack of differentiation boundaries that differentiate it from adults (Makryniotis, 1986). The child is treated as an adult 
miniature in the first Pedagogies published in the Greek-speaking area (Mosiodax, 1779 and Kallonas, 1800) and is described metaphorically (Noutsos, 1986) as "soft wax", "plastic clay", "marble sponge" or "blank table" (=tabula rasa). This parallelism defines parents and teachers as responsible for the development of the child and offers the epistemological and psychological basis on which child education becomes a national priority. This position is tempered by Jean-Jacques Rousseau's selective position for the school, which Konstantinos Koumas (1777-1836) introduces to the Greek-speaking world (Koumas, 1819). In this direction, Dimitrios Katartzis (1783) and Dimitrios Darvaris (1791) treat the child as a separate entity, as a person with different needs from the adult and childhood cease to be an indefinite "vestibule" of adulthood. In their work, child-centered, the exploitation of pedagogical interest and the active participation of pupils in the learning process are evident.

In the first years after the independence of the Greek State, children's education is strictly disciplinary. It starts from the close monitoring of the students and with a series of sentences reaches their public protest (Dimaras, 1999). In addition to this, it is necessary to add the series of penalties to the cervical plaque provided by Louis-Charles Sarazin's Monitorial Education Guide (1797-1865), which was translated in Greek by the educator Ioannis Kokkonis (1796-1864). According to the Monitorial Education Guide, the student is obligated to follow the teacher's instructions, from which it appears that the character of the child is considered to be mild and both the teacher and the state expect a similar behavior to that of the adult. Everything that suits the children's special character and psychosis is forbidden. A typical example is the game, which is an activity almost forbidding for student: “...the teacher must strictly prohibit the gatherings and toys on the streets...” (Kokkonis, 1860³, $\mathrm{p}$. 292). Every action of the child is closely monitored by the teacher, contrary to what Jean-Jacques Rousseau claims. In this educational act, of course, criticism is exercised by a number of educators. The view of Neophytos Vamvas is characteristic: "...Instead of being brought to the innocent children in a sweet and subtle way, they treat both the look and the voice, and the hands with tyranny. Instead of feeding on their natural curiosity and their stature with stories and descriptions of animals, plants, etc. they spend all day with naughty spells and temporary readings... Children's spirits are humiliated, and rightly feel sorry for learning and unholy hatred against the tyrants of their innocent age...” (Dimaras, 1999, p. 9). In the last quarter of the 19th century, the views of Johann Heinrich Pestalozzi (1746-1827), mainly through his student Friedrich Wilhelm August Fröbel (1782-1852) and the work of Aikaterini Laskaridou (1842-1916) and of Johann Friedrich Herbart (1776-1841), mainly through his students, Karl Volkmar Stoy (1815-1885), Tuiskon Ziller (1817-1883) and Wilhelm Rein (1847-1929), concerning child and childhood. The process of treatment has a starting point for the individual (Kontomitros, 2006). In this direction the child is still defined as the "educated person", adopting as the most important condition of the treatment the pliable nature of the food. In this context, the discipline measures taken by the teacher are also lacking, as the nature of the child tends towards disaster (Lindner, $1892^{2}$ ). At the beginning of the 20th century, the development of Psychology (James, Jenks, Prout, 20078) shapes the likeness of the child as a "growing plant", which implies the spread of new pedagogical concepts. These are the liberal perceptions of the so-called "New Education", which are directly linked to the dominant pedagogical slogan of the time: from the child (Röhrs, 1984; Grollios, 2011). These concepts are adopted in Greece by the demoticistic educators and pedagogues who are concerned with the individual or social aspect of the education. Alexandros Delmuzos, undergoing social education, emphasizes that "man does not live alone, with himself and for himself, despite living always and in everyday life" (Delmouzos, 1929, p. 34). Therefore, the school institution should have been centered in "not the child, but the children" (Delmouzos, 1929, p. 75). In this context, particular emphasis is placed on school life, which puts students in real situations: school holidays, excursions, walks, manual work, institution of self-government, pedagogical utilization of playing (Terzis, $\left.2006^{2}\right)$.

\subsection{From the Teacher-Centered to Child-Centered Education}

The teacher-student relationship is based in both 18th and 19th centuries exclusively on the authority of the former and on 
the fear, obedience, and discipline of the latter. Education is purely teacher-centered, which is compounded by the choice of the monitorial method. In the internal regulations of the Gymnasiums and Hellenic Schools of 1857 is emphasized that "the student owes love, respect and obedience to his teacher" (Dimaras, 1999, p. 157). The pedagogical relationship is unilateral. Discipline and subordination are imposed on students both by the monitorial method and the discipline measures, which resulting from its application, as well as by external characteristics of uniformity, such as the establishment (1876) of the standard outfit worn by students of the Gymnasium and the Hellenic Schools (Dimaras, 1999). The State recognizes only obligations to students, not rights.

The monitorial method is abolished in 1880 and co-teaching is adopted, while at the same time the first scholarship students in the Pedagogy are sent to Germany, and the memorization and the unaccountable retirement are gradually abolished. The questioning of the education provided and the pedagogical methods is not limited to Primary School but extends to Preschool, Secondary and Higher Education and also concerns both the education of boys and the education of girls (Kyprianos, 2004).

From the beginning of the 20th century childhood is gradually defined as the object of scientific research and study in Greece. In 1910 the General Inspector of Elementary Education, Georgios Drosinis, suggests the founding of a pedology workshop. In 1912 the professor of Pedology, Emmanuel Lampadarios gives ten lectures about the topic of Pedology at the Normal School of Secondary Education. Furthermore, the initiators of the educational reform of 1917-1920 issue two new school books and transcribe or process eleven more, focusing on the child and his interests. The school atmosphere is impregnated with images of everyday life, a radically different teaching and learning process and a child-centered pedagogical relationship (Terzis, 201333). In 1919 the work of Alfred Binet titled New ideas for the child is translated by Christodoulos Lefas, and in 1920-1921 doctor Konstantinos Charitakis publishes the first relevant magazine with the title Pedology. The Minister of Education Dimitrios Digkas with an encyclical invites educators to study the magazine's articles, since he thinks that the study of the contents of the magazine will help them in their work (Encyclical 12430/21 March 1920).

Contributors to the magazine include some very important Modern Greek educators -Alexandros Delmouzos, Dimitris Glinos, Dimitrios Lampsas, and Michalis Papamavrou- who refer to the physical and mental evolution of the child influenced by the principles of Progressive Education and W. Wundt's ideas. The child is now approached not only as a soul, but also as a body. In this way particular emphasis is placed on experimental pedagogy and child psychology (Ziogou, Foukas, Chatzimpei, 2010). The notion of "human nature" is gradually replaced by the notion of the "child's nature".

This whole debate peaks in 1923, when the educator Dimitris Glinos argues that the right simile for the education process is no longer that of a creator who takes in his hands clay and gives it form, or of a sculptor who creates in marble an image that he has in mind. The child is a plant that will bloom and bear fruit and has within him his future strength. Inside the child there is the basic potential, the general impetus and the main directions for his development (Glinos, 1971).

Using this framework, from 1924 until 1930, the Association for the Distribution of Beneficial Books publishes five books concerning children and childhood. Modern Greek educators will depend on this new scientific approach of the child in order to organize education on the basis of the distinction of children in psychological types (Delmouzos, 1929). During this period there are important translations of books: in 1924 Aristotle Kourtidis translates the first book about Montessori, and in 1926, Kostas Sotiriou translates Dewey's book entitled, The school and the child.

Alexandros Delmouzos, professor of pedagogy in the Faculty of Philosophy at Aristotle University of Thessaloniki since 1928, includes in his teaching a unit relevant to the psychology of the child, his mental and physical development, and his interest for knowledge, while he also includes in the syllabus excerpts from Dewey's book, which was translated by 
Kostas Sotiriou (Foukas, 2010).

These concepts, however, do not eventually prevail, since the traditional ideological structure of Greek society resists modernisation (Terzis, 1993). Thus, in Modern Greek thinking about education we can observe peculiar pedagogical mixtures (Noutsos, 1986).

\subsection{Health Policies for Children}

In the first decades of the 20th century the emphasis given by the Greek government to issues of school hygiene contributes to the study of pedology and its development as an independent science. Child mortality, which in Greece in 1920 reaches 10.6 percent for children aged 6 to 10 and 6.7 percent for children aged 10 to 15 , is due mainly to the ignorance of parents about the importance of hygiene in the feeding and care of babies. For this reason the state makes provision for the establishment school doctors and emphasis is placed on the hygiene of both students and schools. Despite the initial fears and doubts of teachers, the school doctor becomes their basic co-worker and assistant and contributes to the child's physical and mental development (Lampadarios, 1928²).

On 27 May 1920 the Greek Pedologic Association is established. Among the members of the association's board of directors there are some well known Greek educators (e.g. Dimitrios Glinos, Alexandros Delmouzos, Dimitrios Lampsas, Dimitrios Georgakakis, Aikaterini Varouxaki, Myrsini Kleanthous, Ioannis Vainopoulos, Ioannis Vachaviolos, Zisis Zamanis, Nikolaos Kapetanakis, Aristotelis Kourtidis, Michalis Papamavrou). President of the association is the professor of pediatrics, Christos Malandrinos who notes after his election: "[...] The child needs a lot of attention. The child is the father of the human being and we must study it, take care of it and protect it...” (Pedology, 1920, pp. 72-73).

The basic aims of the association cited in its charter can be summarised as follows: a) organisation of lectures, lessons and conferences, b) publication of specialised magazines, scientific works, popularised studies and practical advice, c) establishment of a pedologic workshop, museum, pedologic library, model school, d) suggestions to the appropriate services of measures for the child's protection and e) communication with similar agencies abroad (Charter of the Greek Pedologic Association, article 2).

Lampadarios referring to the relationship between pedology and pedagogy writes in 1928: "[...] So, the true educator ought to know pedology and have precise knowledge about the physical, mental and moral condition of the student..." (Lampadarios, 1928², p. 9).

He also suggests the establishment of an autonomous section of pedology in the university (Pedology, 1920). The child starts becoming the object of study and it is suggested that it should become the main concern for fathers as well as mothers (Pedology, 1920).

In the period under consideration, the first textbooks of hygiene, in which the child is the basic object of study and research, are being written and published (Theodorou \& Karakatsani, 2003). This whole discussion leads the state to think about the establishment of a separate Ministry of National Health and Social Care (Pedology, 1920).

At the same time, we should mention the gradual increase in the number of hours devoted to the teaching of gymnastics in secondary schools, from the beginning of the 20th century, since gymnastics is considered to significantly contribute to the physical and mental health of students (Antoniou, 1989). In the hygiene textbooks that are published in Greece, the relationship between hygiene and gymnastics is highlighted since gymnastics helps respiratory function and blood circulation in children (Lampadarios, 1928²). In 1920 special courses in gymnastics are created for girls (Law 2476/ 24-61920).

\section{Conclusion}


From all the above, it is clear that as far as the Greek educational reality is concerned, from the 19th century to the first decades of the 20th century, the main features of the child, as reflected in pedagogical theory and affecting their rights in education, can to be outlined in two main categories: on the one hand, the child is characterized by a soft character and weakness ("little adult") and on the other by spontaneity, curiosity, joy and movement ("New Era" movement). The general demand for the expansion and elevation of compulsory primary school education at the end of the 19th century (with the 1899 Education Bills of the Education Minister Athanasios Eutaxias) and in the beginning of the 20th century (1913 Education Bills of Ioannis Tsirimokos) creates positive conditions for the transition from pedagogic theory that sees the child as a "little adult" in experimental pedagogy, to the study and development of child psychology and an emphasis on the natural capabilities of the child. Children are educated for the roles and responsibilities that they will assume as future citizens of their society. The most common approach to rights education is the "not-yet" approach. This approach does not recognize the citizenship and rightsbearing status of children.

Both of these categories have implications for the educational process and the everyday life of the pupil in the classroom: The fans of the first group treat the child as "property" and "subject" fully dependent on adults and consider that interpersonal relationships between parent and child and between teacher and student should be characterized by respect and obedience to the first one but also by punishments of adults to the student, even physical. On the other hand, supporters of the second group claim that the child is supple, but his adults simply offer the right environment to move his curiosity and mood for exploration and further learning based on his personal interests. Thus, at the level of educational activities, during the 18th and 19th centuries, we observe freedom in pedagogic measures. The issuing of many ministerial encyclicals for the prohibition of corporal punishment $(1848,1854,1867$ and 1884) expresses that reality. The school memories from some students of those eras published in magazines are characteristic. It will take the diffusion of the ideas of Progressive Education to go from child discipline to the idea of penalties and rewards.

At the socio-political level: the child is used as a means of achieving some of the aims of the state. At times when youth is considered responsible for disorder and subversion (the 1860s, for example) educators regard the shaping of children through education as a way of resolving such situations. Meanwhile, Fotis Fotiadis in 1902 calls for the overthrow of existing educational conditions and for the adoption and diffusion of new educational demands: "The children are our desires, hopes for a better future" (Fotiadis, 1902, p. 401).

\section{References}

(1926). Democracy and Education. Our Educational Program. Anagennisis, 1(3), 182-184. [in Greek]

Antoniou, D. (1989). Curriculum of Secondary Education, 1833-1929. Vol. 3 (pp.85-123), Athens: HAGY - GSY. [in Greek]

Charter of the Greek Pedologic Association, Article 2. [in Greek]

Delmouzos, A1. (1929). The First Efforts in the Marasleio School of 1923-1926. Athens: Dimitrakou. [in Greek]

Dimaras, Al. (1999). The Reform Has Not Happened. Evidence of History. Athens: Estia. [in Greek]

Fotiadis, F. (1902). The Linguistic Issue and Our Educational Rebirth. Athens: Estia. [in Greek]

Foukas, V. (2010). The Faculty of the University of Thessaloniki: Studying, Students and Female Students during the Interwar Period (19261940). Thessaloniki: Kyriakidis Brothers Publishing House. [in Greek]

Glinos, D. (1971). The Basic Problem of Education. In Glinos, D., Chosen pages, V. 1, Athens: Stochastis. [in Greek]

Grollios, G. (2011). Progressive Education and Curriculum. Thessaloniki: Epikentro. [in Greek]

James, Al., \& Ad. James (2008). Key Concepts in Childhood Studies. (pp. 22-25). SAGE Publications Ltd,

James, Al., Jenks, Chr., \& Prout, Al. (2007). Theorizing Childhood (8th ed.). Cambridge: Polity Press.

Jenks. Chr. (ed.) (2005). Childhood. Critical Concepts in Sociology. Vol. 3 (pp. 271-367). London: Routledge.

Kallonas, G. (1800). Pedagogy, Containing Very Useful Tips and Rules on How to Raise Children. Vienna. [in Greek] 
Kitromilidis, P. (2004). A Citizen of Geneva (5th ed.). In Kitromilidis, P., Political Thinkers of Younger Years. Biographical and Interpretive Approaches. Athens: Poreia. [in Greek]

Kokkonis, J. P. (1860). Handbook or Guide for the Monitorial Method for Elementary Schools (3rd ed.). Athens: Nikolaidou. [in Greek]

Kontomitros, G. (2006). The German Reform Pedagogical and the Effects of the Greek Education during the First Decades of the 20th Century. Volos: University of Thessaly. [in Greek]

Koumas, K. M. (1819). On Education. Hermes o Logios, 19, 730-748. [in Greek]

Kyprianos, P. (2004). Comparative History of Greek Education. Athens: Vivliorama. [in Greek]

Lampadarios, Emm. (1928). School Hygiene (2nd ed.). Athens: Sfendonis. [in Greek]

Lindner, G. A. (1892). General Pedagogy and Teaching (2nd ed.). Trans. Christos Papadopoulos. Athens: Kousoulinis. [in Greek]

Makryniotis, D. (1986). The Childhood in Reading Books 1834-1919. Athens: Editions Dodoni. [in Greek]

Martinegou-Moutzan, El. (1956). Autobiography. Athens: Digenis. [in Greek]

Moisiodax, I. (1779). Treatise about Children's Education or Pedagogy. Venice. [in Greek]

Noutsos, Ch. (1986). The Simile for the Child in the Modern Greek Pedagogy. In: Historicity of Childhood and Youth. Vol. 2. (pp. 449-456). Athens: HAG.Y - GSY. [in Greek]

Panayiotatou, Ang. (1951). The Struggle of My Life. Athens: Alexandria. [in Greek]

Röhrs, H. (1984). The Progressive Education Movement. Trans. K. Delikonstantis \& S. Bouzakis. Thessaloniki: Kyriakidis Brothers Publishing House. [in Greek]

Terzis, N. (1993). Educational Policy and Educational Reformation: Program and Reality-Things and Persons. Thessaloniki: Kyriakidis Brothers Publishing House. [in Greek]

Terzis, N. P. (2004). Thoughts on the Greek Education during the Ottoman Period with Emphasis on the Upper Course of Study in Patriarchal Seminary of Constantinople (1759-1821): A New Perspective on an Old Issue. In The Patriarchal Great School: History and Offer (pp. 17-59). Athens: Society for the Study of Our Regions. [in Greek]

Terzis, N. P. (2006). The Pedagogy of Alexandros P. Delmouzos: A Systematic Examination of the Project and of Its Action (2nd ed.). Thessaloniki: Kyriakidis Brothers Publishing House. [in Greek]

Terzis, N. P. (2013). Study of Neoellinism Training: Before the State-by the State-out of the State (3rd ed.). Thessaloniki: Kyriakidis Versions. [in Greek]

Theodorou, V., \& Karakatsani, D. (2003). The Movement of the Outdoors Training in the First Decades of the 20th Century. Social Perception and Medical- Pedagogical Searching. Issues of History of Education, 2, 55-78. [in Greek]

Tzikas, Chr. (2008). Funding of Education and Access to School: An Example from the Primary School of the 19th Century. In 5th Scientific Congress of History Education with Education and Social Justice. Patra: http://www.eriande.elemedu.upatras.gr. [in Greek]

Ziogou, S., Foukas, V., \& Chatzimpei, P. (2010). Childhood and Pedagogical Theory in Greece (19th-First Decades of the 20th Century): From "the Small Adult" to the "Child's Psychology". In Hopkins, L., Macleod, M., Turgeon, W. C. (eds). Negotiating Childhoods (pp. 8797). Oxford, U.K: Inter-Disciplinary Press.

Ziogou-Karastergiou, S. (1986). The Secondary Education of Girls in Greece (1830-1893). Athens: Greek Youth-G.G.N.G. [in Greek]

Ziogou-Karastergiou, S. (2006). Exploring Gender. Historical Dimension and Contemporary Thinking in General, Vocational and continuing education. Thessaloniki: Vanias. [in Greek] 